\title{
ANALYSIS OF POTENTIAL PHYSICO CHEMICAL WATER QUALITY PARAMETERS OF ELENGENA BEEL, JAGIROAD, MORIGAON, ASSAM
}

\section{JAYANTA KUMAR BORA, ${ }^{* 2}$ MD. Y. HASSAN AND ${ }^{3}$ M. BURAGOHAIN}

\author{
${ }^{1}$ Research Scholar, Faculty of Sciences, Assam down town University, Guwahati, Assam, India \\ ${ }^{2}$ Research Supervisor, Department of Chemistry, Assam down town University, Guwahati, Assam, \\ India \\ ${ }^{3}$ Associate Professor, Department of Chemistry, Lakhimpur Girls' College, North Lakhimpur, \\ Assam, India \\ *Corresponding author’s email: yaminhassan81@rediffmail.com
}

\begin{abstract}
The study was made to investigate the potential physico-chemical water quality of Elengena beel. In this study 40 nos water samples were collected from 4 sampling sites (10 from each) of Elengena beel and had been analyzed for some water quality parameters and ranges of results were found as - water temperature, transperancy, depth, $\mathrm{pH}$, dissolved oxygen (DO), biological oxygen demand (BOD), chemical oxygen demand (COD), total dissolved solids (TDS), total suspended solids (TSS), total solids (TS), total alkalinity (TA), total hardness (TH), chloride (Cl-) and fluoride $(\mathrm{F}-)$. silicates $\left(\mathrm{SiO}_{2}\right)$, free carbondioxide $\left(\mathrm{FCO}_{2}\right)$, nitrate $\left(\mathrm{NO}_{3}{ }^{-}\right)$, phosphate $\left(\mathrm{PO}_{4}{ }^{3-}\right)$, colour and odour. Nutrients were determined by following the standard procedures outlined in the American Public Health Association (APHA). The result showed that water temperature, transperancy, depth, $\mathrm{pH}, \mathrm{DO}, \mathrm{BOD}, \mathrm{COD}, \mathrm{TA}, \mathrm{TH}, \mathrm{TS}, \mathrm{TDS}, \mathrm{SiO}_{2}, \mathrm{~F}_{-} \mathrm{CO}_{2}, \mathrm{Cl}^{-}, \mathrm{NO}_{3}{ }^{-}$, and $\mathrm{PO}_{4}{ }^{3-}$ were $19.9 \pm 0.28 ; 21.5 \pm 0.71 ; 1.0 \pm 0.23 ; 6.8 \pm 0.15 ; 4.1 \pm 0.34 ; 51.8 \pm 2.32 ; 58.61 \pm 3.22 ; 156.2 \pm$ $1.2 ; 210.5 \pm 0.2 ; 153.8 \pm 0.90 ; 170.2 \pm 0.60 ; 49.2 \pm 0.85 ; 2.87 \pm 0.02 ; 10.91 \pm 1.32 ; 0.20 \pm$ 0.01 and $0.10 \pm 0.1 \mathrm{mg} / \mathrm{L}$ respectively. All the measured parameters were within the standard values of WHO. In general the present investigation found that the maximum parameters were not at a level of pollution. In order to stop further deterioration of Elengena beel water quality and to eventually restore the beneficial uses of the beel, management of effluents of Nagaon paper mill in the beel watershed should be given urgent priority.
\end{abstract}

KEY WORDS: physico-chemical parameters, Elengena beel, Morigaon district, Assam, India 


\section{INTRODUCTION}

Water is one of the most important and most precious natural resources. It is essential in the life of all living organisms from the simplest plant and microorganisms to the most complex living system known as human body. It is significant due to its unique chemical and physical properties (Onifade, A.K. et al 2008, Osci, Y. 2005 and Obi, C.N, 2007). Increase in population, modernization, extra wastes and throughout have their own roles in the changing environment. Water resources are being polluted due to which an imbalance is created in streams, rivers, ponds, beels or freshwater ecosystem. The unwanted change in the physical, chemical and biological factors of freshwater habitat and the deterioration of water quality have imposed a serious threat to the very existence of civilization. The physical and chemical characteristics of any lake under natural conditions are influenced by a number of factors including topography, geology and inputs through rainwater, water/rock interactions and climate variability (Han et al., 2004). Lake systems are also influenced by anthropogenic factors of the people residing in the watershed; disturbance due to pollution and other human interferences giving rise to specific problems (Yezbie, K. et al., 2019) that correlate with the changes of the respective factors mentioned above. Idealy the quality of water should be assessed on the basis of physicochemical and biological parameters in order to provide complete spectrum of information for water management purposes. The unwanted change in the physical, chemical and biological factors of freshwater habitat and the deterioration of water quality have imposed a serious threat to the very existence of civilization. Studies on water quality and effluent quality is highly important as these water or effluent mixed water are liable for direct consumption by animals and human population. From Nagaon Paper Mill the freshwater receives dark brown foamy colour liquor effluent. Dirty black subsoil with foul smelling gases runs in the freshwater streams of Jagiroad area. A cardboard like layer due to the presence of pulp fibres, silicates and precipitated chemical substances is constantly deposited in the different freshwater bodies or in the nearby beels or in river margin (Haque, A. et al., 2010). Natural water bodies are polluted by improperly treated or partially treated or untreated industrial effluents. Most of the natural waters receive varieties of organic or inorganic substances or heavy metals in huge quantities. In India, there is a considerable discharge of such effluents in to the major rivers. Most of the toxicants released from industries find their way in to the aquatic ecosystem which is an environmental load for which the aquatic organisms experience physiological stress besides other toxicological constraints. The inflow from the catchment area or from the vicinity in the form of foliage, dung, decay matters, effluent run off generally effect the water quality of a beel. The productivity of a lake or a reservoir or a beel, or a pond, therefore, is greatly influenced by its hydrobiological features. Organisms are affected by factors in its environment (Khan, A.H. et al., 2013). 


\section{MATERIALS AND METHODOLOGY}

\section{Morphometry of Elenga Beel}

The location of Elenga beel is $20 \mathrm{~km}$ South-West from Morigaon town, Assam, at Latitude $26^{\circ} 12^{\prime} 10^{\prime \prime}(\mathrm{N})$, Longitude $92^{\circ} 09^{\prime} 53^{\prime}(\mathrm{E})$. The total catchments area of the Elenga Beel is $2.7 \mathrm{~km}^{2}$ with $2.7 \mathrm{~km}^{2}$ of surface area and average depth $1.6 \mathrm{~m}$ (depth range $=1.5-1.7 \mathrm{~m}$ ). The maximum effective length and maximum effective width of Elenga Beel are $2 \mathrm{~km}$ and $1.7 \mathrm{~km}$ respectively. The beels of the district are of mixed type i.e., lake like and ox-bow type. Besides Brahmaputra, Sonai, Kolong and part of Kapili River flows downstream through various parts of the district. Morigaon district is situated in between the Latitude $25^{\circ} 30^{\prime}(\mathrm{N})$ and Longitude $92^{\circ} 15^{\prime}(\mathrm{E})$ on the South bank of the river Bhahmaputra. The total land area of the district is $1587.7 \mathrm{sq} \mathrm{km}$, number of wetlands are 183 covering an area of 11658 ha. (Statistical Hand Book, Assam, 2017).

\section{Sampling Information and Analysis}

The present investigation was carried out in Elenga beel to study the distribution of physico chemical parameters in Elenga Beel ecosystem polluted by Nagaon Paper Mill Effluent. A total of 40 water samples were collected from the four sites of Elenga beel as- Site 1 (East): Below the meeting point towards East Bank; Site 2 (West): Below the meeting point towards West Bank; Site 3 (North): Below the meeting point towards North Bank and Site 4 (South): Below the meeting point towards South Bank. The samples were collected for investigation following the procedure APHA (2005). For water samples, polythene bottles were used for collecting samples without help of funnel or tubes. Three vertical samples (surface, middle and bottom) at each site were taken. Physicochemical analysis of water is categorized as Mineral Analysis consisting of physical parameters and significant ions by adopting following specific methodologies.

Determination of $\mathbf{p H}$ : The $\mathrm{pH}$ of each sample was measured with portable field $\mathrm{pH}$ meter.

Determination of Total Alkalinity (TA): Three drops of bromcresol green indicator was added to $50 \mathrm{~mL}$ of each the samples and titrated with $0.02 \mathrm{~N} \mathrm{H}_{2} \mathrm{SO}_{4}$ to $\mathrm{pH} 4.5$ and total alkalinity was estimated (bromcresol green indicator was changed the color from blue to yellow at $\mathrm{pH} 4.5$ ). Amount of acid used at this moment starting phenolphthalein was used to react with hydroxide, carbonate and bicarbonate and it was constituted of total alkalinity. Finally total alkalinity was calculated as follows:-

$$
\text { A } \times \text { N/2 } \times 50 \times 1000
$$

Total alkalinity $(\mathrm{mg} / \mathrm{L})\left(\right.$ as $\left.\mathrm{CaCO}_{3}\right)=$

\section{$\mathrm{V}$}

$\mathrm{A}=$ Volume of $\mathrm{H} \mathrm{SO}_{4}$ consumed in $\mathrm{mL}$ starting from phenolphthalein, $\mathrm{N}=$ normality of $\mathrm{H}_{2} \mathrm{SO}_{4}$, $\mathrm{V}=$ volume of sample used in $\mathrm{mL}$.

Determination of Total Dissolved Solid (TDS), Total Suspended Solid (TSS) and Total Solid (TS): For total suspended solid (TSS), $100 \mathrm{ml}$ of the water sample of each was filtered through 
a pre weighed filtered paper. The filtered papers were dried at $103-105^{\circ} \mathrm{C}$ in oven and TSS was determined by the following formula.

$$
\begin{aligned}
& \text { filter post weight - filter pre weight x } 1000 \\
& \operatorname{TSS}(\mathrm{mg} / \mathrm{L})= \\
& \text { V sample (ml) }
\end{aligned}
$$

TDS was measured using combined $\mathrm{pH} / \mathrm{T}^{\circ} / \mathrm{TDS}$ and conductivity meter model 4200 whereas TS was measured from the two parameters of TDS and TSS given by

$$
\mathrm{TS}(\mathrm{mg} / \mathrm{L})=\operatorname{TDS}(\mathrm{mg} / \mathrm{L})+\mathrm{TSS}(\mathrm{mg} / \mathrm{L})
$$

Determination of chloride ion: $10 \mathrm{~mL}$ of each water sample was taken in conical flask. And $\mathrm{pH}$ was measured and adjusted in between 7-9. After that $1 \mathrm{~mL}$ of $5 \% \mathrm{~K}_{2} \mathrm{CrO}_{4}$ indicator was added to and titrated with previously standardized silver nitrate solution to brick red color precipitate end point and noted down volume of titrant used as $\mathrm{V}_{1}$. Similarly a blank titration was done by taking $10 \mathrm{~mL}$ of distilled water instead of sample and precedes the same procedure as the sample and recorded the final volume as $\mathrm{V}_{2}$. Finally the concentration of chloride present in the sample was calculated using the following equation.

$$
\text { Chloride ion concentrations }(\mathrm{mg} / \mathrm{L})=\frac{\left(\mathrm{V}_{1}-\mathrm{V}_{2}\right) \times 35.5 \times 1000}{\mathrm{~V}_{\text {sample }}}
$$

Where $\mathrm{V}_{1}=$ volume of titrant consumed for water sample. $\mathrm{V}_{2}=$ Volume of titrant consumed for blank, $\quad \mathrm{N}=$ normality of silver nitrate and $\mathrm{V}_{\text {sample }}=$ volume of sample used $(\mathrm{mL})$.

Determination of total hardness of water: To determine the total hardness of water samples $20 \mathrm{~mL}$ of each of the water samples was pipette out in a washed conical flask. $5 \mathrm{~mL}$ ammonical buffer solution and 2-3 drops of Eriochrome Black-T indicator were added, the color of the solution turns wine red. This solution was titrated against previously standardized EDTA solution taken in the burette until the color changes from wine red to sky blue which indicated the end point. The final reading of the burette was noted and the titration was repeated to get concordant value. Finally using the analytical calculation, total hardness of water sample was determined in terms of $\mathrm{mg} / \mathrm{L}$ of $\mathrm{CaCO}_{3}$.was titrated against previously standardized EDTA solution taken in the burette until the color changes from wine red to sky blue which indicated the end point. The final reading of the burette was noted and the titration was repeated to get concordant value. Finally using the analytical calculation, total hardness of water sample was determined in terms of $\mathrm{mg} / \mathrm{L}$ of $\mathrm{CaCO}_{3}$. 


\section{RESULTS AND DISCUSSION}

Physiochemical characteristics were analyzed and the data are given in Table 1

Table 1: Results of physico-chemical water quality parameters in the study area, Elenga beel, average concentration (Mean $\pm \mathrm{SD}, \mathrm{n}=10$ )

\begin{tabular}{|l|c|c|c|c|}
\hline \multirow{2}{*}{ Parameters } & \multicolumn{4}{|c|}{ Sampling Sites } \\
\cline { 2 - 5 } & Site-1 & Site- 2 & Site-3 & Site- 4 \\
\hline Temp $\left({ }^{0} \mathrm{C}\right)$ & $19.9 \pm 0.28$ & $19.5 \pm 0.33$ & $23.9 \pm 0.28$ & $23.8 \pm 0.17$ \\
\hline $\mathrm{TR}(\mathrm{cm})$ & $21.5 \pm 0.71$ & $23.2 \pm 0.94$ & $23.4 \pm 0.93$ & $31.9 \pm 1.35$ \\
\hline $\mathrm{DPTH}(\mathrm{m})$ & $1.0 \pm 0.23$ & $1.5 \pm 0.08$ & $1.9 \pm 0.21$ & $1.8 \pm 0.46$ \\
\hline $\mathrm{pH}$ & $6.8 \pm 0.15$ & $8.0 \pm 0.35$ & $8.0 \pm 0.28$ & $8.2 \pm 0.21$ \\
\hline $\mathrm{DO}(\mathrm{mg} / \mathrm{L})$ & $4.1 \pm 0.34$ & $4.2 \pm 0.30$ & $3.5 \pm 0.48$ & $3.8 \pm 0.17$ \\
\hline $\mathrm{BOD}(\mathrm{mg} / \mathrm{L})$ & $51.8 \pm 2.32$ & $52.7 \pm 3.22$ & $51.0 \pm 0.96$ & $50.8 \pm 0.75$ \\
\hline $\mathrm{COD}(\mathrm{mg} / \mathrm{L})$ & $58.61 \pm 3.22$ & $60.1 \pm 2.59$ & $59.9 \pm 3.20$ & $57.5 \pm 5.43$ \\
\hline $\mathrm{TA}(\mathrm{mg} / \mathrm{L})$ & $156.2 \pm 1.2$ & $155.1 \pm 0.81$ & $154.1 \pm 2.58$ & $153.2 \pm 1.81$ \\
\hline $\mathrm{TH}(\mathrm{mg} / \mathrm{L})$ & $210.5 \pm 0.2$ & $218.2 \pm 2.3$ & $205.5 \pm 0.60$ & $216.5 \pm 0.4$ \\
\hline $\mathrm{TSS}(\mathrm{mg} / \mathrm{L})$ & $10.2 \pm 0.20$ & $22.5 \pm 0.30$ & $24.4 \pm 0.40$ & $30.2 \pm 0.20$ \\
\hline $\mathrm{TDS}(\mathrm{mg} / \mathrm{L})$ & $170.2 \pm 0.60$ & $165.5 \pm 0.65$ & $154.4 \pm 0.20$ & $154.2 \pm 0.25$ \\
\hline $\mathrm{TS}(\mathrm{mg} / \mathrm{L})$ & $180.4 \pm 0.80$ & $188.0 \pm 0.95$ & $178.8 \pm 0.60$ & $184.4 \pm 0.45$ \\
\hline $\mathrm{SiO}_{2}(\mathrm{mg} / \mathrm{L})$ & $49.2 \pm 0.85$ & $46.8 \pm 0.81$ & $48.2 \pm 0.82$ & $47.3 \pm 0.69$ \\
\hline $\mathrm{F}-\mathrm{CO}_{2}(\mathrm{mg} / \mathrm{L})$ & $2.87 \pm 0.02$ & $2.18 \pm 0.01$ & $1.79 \pm 0.01$ & $1.16 \pm 0.01$ \\
\hline $\mathrm{Cl}^{-}(\mathrm{mg} / \mathrm{L})$ & $10.91 \pm 1.32$ & $10.46 \pm 1.24$ & $9.74 \pm 0.27$ & $10.17 \pm 0.42$ \\
\hline $\mathrm{NO}_{3}{ }^{-}(\mathrm{mg} / \mathrm{L})$ & $0.20 \pm 0.01$ & $0.19 \pm 0.01$ & $0.19 \pm 0.01$ & $0.18 \pm 0.01$ \\
\hline $\mathrm{PO}_{4}{ }^{3-}(\mathrm{mg} / \mathrm{L})$ & $0.10 \pm 0.01$ & $0.09 \pm 0.01$ & $0.10 \pm 0.01$ & $0.09 \pm 0.01$ \\
\hline
\end{tabular}

The $\mathrm{pH}$ is a measure of the hydrogen ion concentration in water. In this study, the concentration of hydrogen ion $(\mathrm{pH})$ ranges between 6.8 to 8.2 and all the water samples analyzed have concentration within the safe limit of 6.5 to 8.5 standard set by the WHO. Thus indicated that the measured $\mathrm{pH}$ values of the water samples were within permissible value of WHO, 2017. The overall result indicates that the water sources are within the desirable and suitable range. Basically, the $\mathrm{pH}$ is determined by the amount of dissolved $\mathrm{CO}_{2}$, which forms carbonic acid in water. $\mathrm{pH}$ of ground water can also be lowered by organic acids from decaying vegetation, or the dissolution of sulfide minerals. The slight basic nature of the bore well water may be mainly due to the limestone basin of the all the locations (Werkneh, A. A. et al., 2015).

Regarding the values of TSS, all the water samples showed less presence of contaminants, as the values ranged from $10.2 \mathrm{mg} / \mathrm{L}$ to $30.2 \mathrm{mg} / \mathrm{L}$. And all these measured values were within the permissible limits of WHO $(\leq 30 \mathrm{mg} / \mathrm{L})$. Similarly the TS values of water samples were ranging from 180.4 to $188.0 \mathrm{mg} / \mathrm{L}$ and all these measured values were also within 
the WHO guide line value which is $500 \mathrm{mg} / \mathrm{L}$. TDS can be taken as an indicator for the general water quality because it directly affects the aesthetic value of the water by increasing turbidity. The acceptable range of TDS is $500 \mathrm{mg} / \mathrm{L}$. In the present study the range of TDS of analyzed water samples varied between 154.2 to $170.2 \mathrm{mg} / \mathrm{L}$. However; all the values were within the standard limit of WHO $(500 \mathrm{mg} / \mathrm{L})$. Alkalinity of water is its acid neutralizing capacity. The alkalinity of water is mainly due to carbonates and bicarbonates. The acceptable limit of alkalinity is $200 \mathrm{mg} / \mathrm{L}$. In the present study alkalinity were determined and the results showed that the total alkalinity of the water samples ranged from 153.2 to $156.2 \mathrm{mg} / \mathrm{L} .200$ and $600 \mathrm{mg} / \mathrm{L}$ respectively. In the present study; the value of total alkalinity content in all sampling sites has been found within the desired limit of WHO $(200 \mathrm{mg} / \mathrm{L})$. In groundwater hardness is mainly contributed by bicarbonates, carbonates, sulphates and chlorides of calcium and magnesium. So, the principal hardness causing ions are calcium and magnesium. The acceptable limit of total hardness is $300 \mathrm{mg} / \mathrm{L}$ whereas the maximum limit is $600 \mathrm{mg} / \mathrm{L}$. The hardness of analyzed water samples varied from 205.5 to $218.2 \mathrm{mg} / \mathrm{L}$ as $\mathrm{CaCO}_{3}$. It has been observed that no water samples are soft but all the measured values were within the acceptable limit values of BIS (300 mg/L) and WHO $(500 \mathrm{mg} / \mathrm{L})$. The concentration of chloride is the indicator of sewage pollution and also imparts laxative effect. The chloride content of studied water samples were within permissible limit of $250 \mathrm{mg} / \mathrm{L}$ prescribed by WHO $(250 \mathrm{mg} / \mathrm{L})$. In present study, the results of chlorides in all sampling sites ranged from 9.74 to $10.91 \mathrm{mg} / \mathrm{L}$.

\section{CONCLUSION}

In this study the collected water samples of Elenga beel were analyzed for physicochemical parameters of water temperature, transperancy, depth, $\mathrm{pH}, \mathrm{DO}, \mathrm{BOD}, \mathrm{COD}, \mathrm{TA}, \mathrm{TH}, \mathrm{TS}, \mathrm{TDS}$, $\mathrm{SiO}_{2}, \mathrm{~F}_{-} \mathrm{CO}_{2}, \mathrm{Cl}^{-}, \mathrm{NO}_{3}{ }^{-}$, and $\mathrm{PO}_{4}{ }^{3-}$. The result revealed that almost all the measured parameters were within the standard water quality given by WHO. In general the present investigation found that the all the water quality parameters of Elenga beel were not at a level of pollution.

\section{ACKNOWLEDGEMENT}

I do acknowledge the authority of Assam down town University, Panikhaiti, Guwahati, Assam, India for allowing and providing me facilities to carry out the work. I do also acknowledge Dr. Bodheswar Kalita of Morigaon College, Morigaon, assam for his constant help and guidance. 


\section{REFERENCES}

APHA. 2005. Standard methods for the examination of water and waste water. Washington, DC: American Public Health Association.

Eatson, A. D., Clesceri, L. S. and Rice, E. W. 2005. Greenberg A E, Standard methods for the examination of water and wastewater (21st ed.), 4-138, Centennial Edition, USA

Han, G. and Liu, C. 2004. Water geochemistry controlled by carbonate dissolution: A study of the river waters draining karst dominated terrain, Guizhou Province, China, 204: 1-10

Haque, A. Kalita, J. C., Deka, D.D and Baruah, B. K. 2010. Effect of effluent water downstream to the Nagaon paper mill, Assam on ovarian follicular population of immature female $\mathrm{C}_{3} \mathrm{H}$ mice, The Biascan Special issue, Vol. 2; ISSN: 0973-7049, 529-535

Khan, A.H., Khan, I., Khan, N. A., Islam, M. and Husain, A. 2013. Reduction of COD of Pulp and paper mill effluent using Sequencing batch reactor, International Journal of Scientific \& Engineering Research, 4 (5), ISSN: 2229-5518, 19-22

Yezbie, K. and Dessie, T. 2019. Analyses of potential heavy metals and physico-chemical water quality parameters on Lake Tana, Ethiopia. J. Acad. Indus. Res. 8(7): 130-138.

Statistical Hand Book, Assam. 2017. Directorate of Economics and Statistics; Govt. of Assam, Guwahati-28

Werkneh, A. A., Medhanit, B. Z., Abay A. K. and Damte. J. Y. 2015. Physico-chemical analysis of drinking water quality at Jigjiga City, Ethiopia, American Journal of Environmental Protection, 4(1), 29-32

WHO. 2017. WHO Guidelines for drinking-water quality, $4^{\text {th }}$ Edition; incorporating the first addendum. Geneva: world health organization. 